\begin{tabular}{|c|c|}
\hline & $\begin{array}{r}\text { Journal of Communication Pedagogy } \\
\qquad 2021, \text { Vol. 4, 96-102 }\end{array}$ \\
\hline $\begin{array}{l}\text { COMMUNICATION } \\
\text { PEDAGOGY }\end{array}$ & $\begin{array}{r}\text { OThe Author(s) } 2021 \\
\text { Reprints and permissions: http://www.csca-netoro }\end{array}$ \\
\hline & $\begin{array}{r}\text { DOI:10.31446/JCP.2021.1.08 } \\
\text { Central States Communication Association }\end{array}$ \\
\hline
\end{tabular}

\title{
Training and Development: Communication and the Multigenerational Workplace
}

\author{
Michael G. Strawser (i)
}

Keywords: instructional communication, training and development, generational differences, multigenerational workplace, millennials, organizational communication

\begin{abstract}
Communication practitioners, especially those who facilitate training and development workshops, should focus on generational differences as a subset of their communication training efforts. This article positions the multigenerational workplace and generational differences as a relevant topic for communication trainers and provides cursory information related to different generations. Ultimately, 10 best practices to address generational differences in business contexts are discussed.
\end{abstract}

I open this essay with a confession: I was initially compelled to study instructional communication because I rebelled against "how I was taught." Throughout my undergraduate experience, lecture was the primary instructional delivery method. Over the years, I have softened my crusade against lecture and now acknowledge it as one tool in an instructor's toolkit. However, I still find myself rebelling against the status quo. In this way, I am a typical millennial.

The word millennial tends to bring forth a variety of reactions, some of them positive and some quite negative. In the corporate world, the millennial appeal has led to substantial training and development content (Freifield, 2018). I offer this essay of best practices for instructional communication when working with millennials because I believe communication scholars are uniquely suited to address generational differences and to adapt instructional methods for success among professional development trainers working in both for corporate and nonprofit contexts (Schullery, 2013). 
Organizations face significant pressure to retain young workers, thus highlighting the importance of consultants and trainers who provide insight into organizational culture, generational identity, and communication (Hughes, 2020). To address these needs, generational training and development is growing in popularity. Thus, this essay proposes data-driven and research-based best practices for communication-based multigenerational workforce training and development.

\section{Generations in the Workplace}

Schullery (2013) argues that a generation consists of those born between a specified year range who share major life experiences including pop culture, economic conditions, and natural disasters. What makes this essay even more important is that five or more generations may be employed in one organization simultaneously (Traditionalists, Baby Boomers, Generation X, Millennials, and Generation Z/iGen). While different generations tend to have different workplace expectations, some core objectives are relatively constant among them. For instance, all generations desire "meaningful work, professional development and advancement opportunities, a positive work-life balance" (Strawser et al., 2019, p. 188). Communication breakdowns often occur, however, based on the various ways such expectations are expressed across generations (Smith, 2019). To clarify, Pollak (2019) posits that the primary difference between generations in the workplace is rooted in communication styles. For example, millennials, the largest group populating the workforce today, crave clear and efficient workplace communication, especially with regard to communication and technology use (Morealle \& Staley, 2016; Watkins \& Smith, 2019). These generational differences may lead to misunderstandings and interpersonal conflict (Bright, 2010). Fortunately, training and development in communication improve corporate climate and reduce conflict by fostering synergy across generations. Ultimately, these factors improve not only employee satisfaction and motivation, but also productivity (Meier \& Cassar, 2018).

Before discussing training and development best practices, however, I first provide operational definitions summarizing characteristics of each generation (see Table 1). These data come from Pew Research Center reports and are to be interpreted as generalizations rather than absolutes (Dimock, 2019).

These generational differences manifest themselves in myriad ways (Taylor, 2014). Because communication researchers are audience analysis experts, Schullery (2013) posits that we are particularly wellsuited for helping managers address communication and conflict successfully among the generations represented in the workplace. Essentially, instructional communication scholars are subject matter experts for workplace training and development (Hall, 2016). Hence, the following paragraphs describe 10 best practices to address generational differences in business contexts based on current training and development literature and experience.

\section{Best Practice 1: Know the Topic}

By "know the topic," I mean we need to include credible voices of scholars representing multiple generations, as well as tailor our examples and approaches in ways that honor generational differences. For instance, trainers are likely to motivate audience members to pay attention when they hear/see scholars representing their generation referenced in the workshop. In addition, accurate birth date ranges for each generation are hot debate topics. In fact, some of these debates led the Pew Research Center to revise birth year categorizations for both millennials and iGen. Moreover, names for each generation are also a topic of debate. While names like baby boomers and millennials have become commonplace, others are not as widely understood. Right now, iGen and Generation $\mathrm{Z}$ are mutually exclusive although 


\begin{tabular}{|c|c|c|}
\hline \multicolumn{3}{|c|}{$\begin{array}{l}\text { TABLE } 1 \\
\text { Generational Differences }\end{array}$} \\
\hline Generation & Year Range & Characteristics \\
\hline Traditionalists & Born Pre-1945 & $\begin{array}{l}\text { This demographic, otherwise known as the Silent Generation, arrived at the } \\
\text { tail end of the "Greatest Generation." Most were born as the Great } \\
\text { Depression and WWII were dying down. Members of this group are rule-fol- } \\
\text { lowers. They are more conservative, traditional, respectful, and sacrificial. }\end{array}$ \\
\hline Baby Boomers & $1946-1964$ & $\begin{array}{l}\text { Depending on the source, Baby Boomers are considered workaholics, } \\
\text { materialistic, and greedy. In addition, Boomers tend to gravitate toward the } \\
\text { concept of the "American Dream" and have (or have had) issues with work/ } \\
\text { life balance. They are also responsible, exceptionally loyal to their children, } \\
\text { and ambitious. }\end{array}$ \\
\hline Generation X & $1965-1980$ & $\begin{array}{l}\text { Members of Gen X are small in number compared to their predecessors and } \\
\text { successors. They are rebellious. They saw their parents work, constantly, } \\
\text { and wanted more balance. They are also independent as many of them had } \\
\text { parents who both worked. X revels in pessimism. They are skeptical, cynical, } \\
\text { and suspicious. }\end{array}$ \\
\hline Millennials & 1981-1996 & $\begin{array}{l}\text { Stereotypes for this group typically include entitled, perfectionist, achieve- } \\
\text { ment-oriented, tolerant, confident, tech-savvy, unfocused, "me"-first, etc. } \\
\text { Millennials have grown up in a world of constant advocacy. Rarely did they } \\
\text { have to fight for themselves because others, specifically their parents, fought } \\
\text { for them. }\end{array}$ \\
\hline Gen Z/iGen & 1997-2012 & $\begin{array}{l}\text { Generation Z grew up in a digital world. They are digital natives and digital } \\
\text { enthusiasts. They tend to have a risk averse existence. This group is entre- } \\
\text { preneurial, image-driven and focused on their personal "brand," and they are } \\
\text { deeply connected to their values and social causes. }\end{array}$ \\
\hline
\end{tabular}

in most circles iGen is the preferred nomenclature. Thus, trainers may find more success using iGen rather than Generation Z referencing Jean Twenge's (2018) work.

\section{Best Practice 2: Start With Theory}

When working with clients in matters related to generational differences, consider using Strauss and Howe (1991) and their work on generational theory as a starting point. Starting with a theoretical framework can help explain difficult concepts. The importance of theory, however, must be balanced with an applied approach. Meaning, do not overcomplicate theoretical dimensions. Use theory as a guide and as evidence to support claims, but translate it to be intelligible to lay audience practitioners.

\section{Best Practice 3: Make the Communication Connection}

Generational differences are a matter of identity, culture, and communication. Do not be afraid to make explicit communication connections for the training audience. Communication is the organization. Making communication connections to generational differences positions the consultant as one who can help with larger issues. If you can help an organization train their people to have more effective relationships across the generational spectrum then, potentially, they will bring you back to work with executives or even work on larger projects. 


\section{Best Practice 4: Survey the Generations}

No matter where training occurs make sure you know something about your audience before the session. At times this can be accomplished by meeting with a supervisor. However, hearing from only one voice may skew what training the trainees really need. When possible complete a needs assessment (Tobey, 2005). A needs assessment can provide insight into your audience and can help quantify what differences and issues really do exist across the generational spectrum. Is it solely knowledge? Do boomers not know what their millennial counterparts want? Or, is it more relational? Does conflict prevent effectiveness? Sometimes you may not be able to adjust training accordingly but even a quick pre-training assessment can help give you targeted insight.

\section{Best Practice 5: Become Familiar With Popular Press Experts}

Our first priority should be to consult academic resources. However, many popular press experts can be extremely helpful. Pollak (2019) is a well-respected and sought-after popular audience generational consultant. I also visit popular press websites, articles, and resources to understand generational differences in the workplace. For those interested, the Harvard Business Review also publishes articles related to generational differences and leadership/management.

\section{Best Practice 6: Tie Generational Differences Into Your Research Agenda}

Generational differences can serve as independent variables in a wide range of studies. For instance, is there a difference in health campaign effectiveness between different generations? Does generation affiliation impact intercultural competence? Infusing generational differences into your research can reinforce expertise and help you achieve additional notoriety as an academic by publishing additional scholarly articles on the subject.

\section{Best Practice 7: Familiarize Yourself With Talent Optimization}

Some training and development conversations with clients seem to really focus on significant issues like culture, relationships, and human resources. For communication scholars and educators who may not be familiar with human resources, it may be worthwhile associating yourself with talent optimization and recruitment/retention strategies. We often hear that generations have different expectations in the workplace (Parry \& Urwin, 2017); however, we addressed earlier that expectations are generally similar. Where managers can benefit from communication training and development about the generations is talent optimization. What motivates a millennial or iGen employee to engage differs from that of a traditionalist or baby boomer. For example, an employer or manager from the traditionalist generation may assign a task to iGen employees and expect them to comply simply out of respect for authority. However, they are likely to be more successful in motivating these employees to perform a task by offering some freedom for entrepreneurial thinking and creativity regarding how they do so. Again, success is rooted in communication training and development around audience analysis and job description tailoring.

\section{Best Practice 8: Know the Business and Communicate Your Market Value}

Communicating generational consulting deliverables in monetary terms can lead to more success with a client initially while building toward a long-term relationship. This is hard to do without thorough 
knowledge of the company and the industry or without access to key performance indicators. Therefore, do your research when and where you can. If you can articulate how positive generational relationships, reverse mentoring, or other key components of generational consulting may help the bottom line you will be well on your way to a valuable training and development experience.

\section{Best Practice 9: Publicize Your Efforts}

Engagement in public scholarship can help build your brand and reinforce your expertise. There are numerous ways you can engage different audiences. Radio hosts and even local morning shows are always looking for experts or content. In addition, popular press outlets, like local business publications, or online periodicals, are interested in generational differences. There are numerous examples of popular press submissions related to generational differences already on the market (Strawser, 2018, 2019). You can carve your own path as a generational expert by taking your research and translating it for the public. Also, you should establish a website that emphasizes your public training and development persona (Legacy Communication, 2020).

\section{Best Practice 10: Start at Home}

If you are in higher education, your students will provide insight into their wants and needs as well as workplace communication expectations. Not all training and development professionals have access to a population as information-rich as our students. This is invaluable. You have access to incredible knowledge in this regard. I am a proponent of using my students as a case study, asking them about their workplace experiences, and then using that information to inform my clients.

Generational expertise is desirable not just in the professional workplace but our own higher education institutions as well. Be willing to work with other academic departments at your institution to provide insight into their students. Instructional preferences are certainly different from workplace expectations, but we can be calculated with how we teach students based on current generation research. If you understand communication expectations of Generation $Z$ you can adjust your classroom communication frequency and modality. You can then be a resource beyond the academy but also within your institution as well.

\section{Generational Content}

The general best practices are offered as tools to think strategically about generational differences when designing communication training and development workshops. The next section focuses specifically on some cautions to consider as well.

\section{Generational Differences Are Stereotypes, Not Prejudices}

Preface your generational training by reminding the audience that at their core generational differences are stereotypes. In essence that's the point. We are trying to identify generalizable traits about a group of people who have been born 15-20 years apart. If unchecked though these stereotypes can lead to prejudices. By now you are probably aware of the "Okay, Boomer" movement. Millennials too have been typecast for years (Rentz, 2015). Our differences need not lead to negative prejudices. Instead, celebrate generational differences when you train and highlight how unique skills can transform the workplace. 


\section{Contextualize Generational Differences}

Generic generation training is everywhere. There are already pre-established training curricula related to generational differences one can easily find online. The key is to take generational research and contextualize it for that industry. For example, think about training as it relates to the culture of the organization first and as it relates then to the clients or customers. If you are focused on hospitality, generational differences will impact relationships; if you are an insurance agency, generational differences will impact sales; and so on. The best trainers can take even the most generic information and apply it to specific situations to maximize value.

\section{Understand Your Outcome}

What do you (or your client) want to accomplish with this training? In most cases the end goal is probably to increase generational intelligence and subsequently to equip high-performing teams. No matter the goal, make sure to provide avenues to assess your effectiveness.

\section{Become a Generational Consultant}

These best practices are not exhaustive but could include communication training and development practices and outcomes based on generational audience analysis and adaptation. As communication scholars, our understanding of culture, identity, engagement, technology, and now generational considerations, may serve as valuable training and development resources in the increasingly diverse workplace today and tomorrow.

\section{References}

Bright, L. (2010). Why age matters in the work preferences of public employees: A comparison of three age-related explanations. Public Personnel Management, 39, 1-14. https://doi.org/10.1177 $\% 2 F 009102601003900101$

Dimock, M. (2019, January 17). Defining generations: Where millennials end and generation Z begins. Pew Research Center. http://web.archive.org/web/20210518143824/https://www.pewresearch.org/ fact-tank/2019/01/17/where-millennials-end-and-generation-z-begins\%20/

Freifield, L. (2018, November/December). 2018 training industry report. Training Magazine. https:// trainingmag.com/sites/default/files/trn-2018-industry-report.pdf

Hall, A. (2016). Exploring the workplace communication preferences of millennials. Journal of Organizational Culture, Communications and Conflict, 20, 35-44. https://www.researchgate.net/publication/ 320146029

Hughes, J. (2020, February 19). Need to keep Gen Z workers happy? Hire a generational consultant. New York Times. https://www.nytimes.com/interactive/2020/02/19/magazine/millennials-gen-z-consulting. html

Legacy Communication. (2020, April 9). Services. https://legacyctc.com/services

Meier, S., \& Cassar, L. (2018). Stop talking about how CSR helps your bottom line. Harvard Business Review, 31. https://hbr.org/2018/01/stop-talking-about-how-csr-helps-your-bottom-line

Morreale, S. P., \& Staley, C. M. (2016). Millennials, teaching and learning, and the elephant in the college classroom. Communication Education, 65(3), 370-373. https://doi.org/10.1080/03634523.2016.11778 42 
Parry, E., \& Urwin, P. (2017). Evidence base for generational differences: Where do we go from here? Work, Aging, and Retirement, 3, 140-148. https://doi.org/10.1093/workar/waw037

Pollak, L. (2019). The remix: How to lead and succeed in the multigenerational workplace. Harper Business.

Rentz, K. C. (2015). Beyond the generational stereotypes: A study of U.S. generation Y employees in context. Business and Professional Communication Quarterly, 78, 136-166. https://doi. org/10.1177/2329490615576183

Schullery, N. M. (2013). Workplace engagement and generational differences in values. Business Communication Quarterly, 76(2), 252-265. https://doi.org/10.1177\%2F1080569913476543

Smith, S. (2019). Millennial faculty expectations of communication. In M. G. Strawser (Ed.), Leading millennial faculty (pp. 73-86). Lexington Books.

Strauss, W., \& Howe, N. (1991). Generations: The history of America's future, 1584-2069. Quill.

Strawser, M. G. (2018, May 4). Millennials will rule the world so figure out how to work with them. Courier Journal. https://www.courier-journal.com/story/opinion/contributors/2018/05/04/millennial-workersskills-available-smart-bosses/580512002/

Strawser, M. G. (2019, July 8). Creating a generation-agnostic workplace. Orlando Business Journal. https://www.bizjournals.com/orlando/news/2019/07/08/millennials-vs-baby-boomers-heres-a-betterway-to.html

Strawser, M. G., Coffey, L., \& Martin, J. (2019). Millennial cultural transitions: Higher education experience as an expectation for workplace culture. In M. Z. Ashlock \& A. Atay (Eds.), Examining millennials reshaping organizational cultures: From theory to practice (pp. 175-192). Lexington Books.

Taylor, P. (2014). The next America: Boomers, millennials, and the looming generational showdown. Public Affairs.

Tobey, D. (2005). Needs assessment basics. Association for Talent Development.

Twenge, J. (2018). iGen: Why today's super-connected kids are growing up less rebellious, more tolerant, less happy-And completely unprepared for adulthood-And what that means for the rest of us. Atria Books.

Watkins, B., \& Smith, S. A. (2019). Best practices for communicating workplace culture on social media. In S. A. Smith (Ed.), Recruitment, retention, and engagement of a millennial workforce (pp. 37-48). Lexington Books. 